\title{
Mimics of Small Ribozymes Utilizing a Supramolecular Scaffold
}

\author{
Tuomas A. Lönnberg, ${ }^{* a}$ Mia Helkearo, ${ }^{a}$ Attila Jancsó ${ }^{b}$ and Tamás Gajda* ${ }^{* b}$ \\ Received (in $X X X, X X X)$ Xth $X X X X X X X X X 20 X X$, Accepted Xth $X X X X X X X X X 20 X X$ \\ DOI: 10.1039/b000000x
}

${ }_{5}$ For elucidating the mechanism of the general acid/base catalysis of the hydrolysis of RNA phosphodiester bonds, a number of cleaving agents having two cyclen moieties tethered to a 1,3,5-triazine core have been prepared and their ability to bind and cleave UpU studied over a wide $\mathrm{pH}$ range. Around neutral $\mathrm{pH}$, the cleaving agents form a highly stable ternary complex with $\mathrm{UpU}$ and $\mathrm{Zn}{ }^{\mathrm{II}}$ through coordination of the uracil $\mathrm{N} 3$ and the cyclen nitrogen atoms to the $\mathrm{Zn}{ }^{\mathrm{II}}$ ions. Under conditions where the triazine core exists

10 in the deprotonated neutral form, hydrolysis of UpU, but not of ApA, is accelerated by approximately two orders of magnitude in the presence of the cleaving agents, suggesting general base rather than metal ion catalysis. The probable mechanism of the observed catalysis and implications to understanding the general acid/base-catalyzed phosphodiester hydrolysis by ribozymes are discussed.

\section{Introduction}

15 An increasing number of cases are reported, where nucleobases of a ribozyme function as general acid/base catalysts for the cleavage of phosphodiester bonds. ${ }^{1}$ General acid/base catalysis of RNA cleavage has been extensively studied with simple buffer acids and bases, such as imidazole, morpholine or acetic acid. In 20 such systems, the observed catalysis is so weak that high buffer concentrations have to be employed, making elimination of medium effects difficult. The results are, hence, somewhat controversial and still open to various interpretations. ${ }^{2}$ One approach to bring the local concentration of the general acid/base 25 catalyst to a sufficient level without causing undesired solvent effects is to anchor the catalyst close to the scissile phosphodiester linkage. Perhaps the most obvious way to achieve this would be to exploit Watson-Crick base-pairing between two complementary oligonucleotides. Owing to the stacking of 30 contiguous base-pairs such hybridization, however, forces the $5^{\prime}$ leaving group into an equatorial position within the phosphorane intermediate, effectively preventing cleavage. ${ }^{3}$

In this paper we apply another type of scaffold for bringing a catalytic group close to the phosphodiester linkage of uridylyl35 3',5'-uridine (UpU). The underlying idea is to anchor the catalyst to the uracil bases with the aid of a scaffold that is sufficiently flexible to allow the departing 5 -linked nucleoside to adopt an apical position within the phosphorane intermediate. The anchoring is based on the strong binding of $\mathrm{Zn}^{\mathrm{II}}$ chelates of small

40 azacrowns to the deprotonated N3 atom of a uracil base, first reported by Kimura. ${ }^{4}$ The soundness of this approach has been previously demonstrated with related di- and trinuclear azacrown derivatives (1a, 1b), which have been shown to form a highly stable complex with UpU. The binuclear bis(azacrown) 45 compound (1b) lacks the catalytic functionality since both of its $\mathrm{Zn}^{\mathrm{II}}$-chelates are engaged in binding to the uracil bases, but still

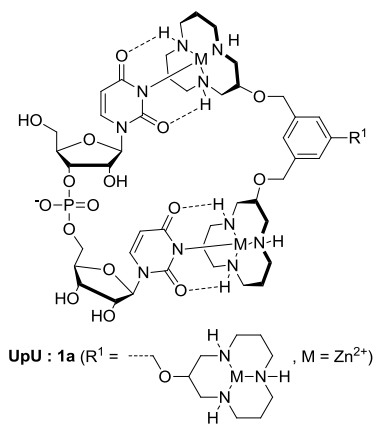

UpU : $\mathbf{1 b}\left(R^{1}=H, M=Z n^{2+}\right)$

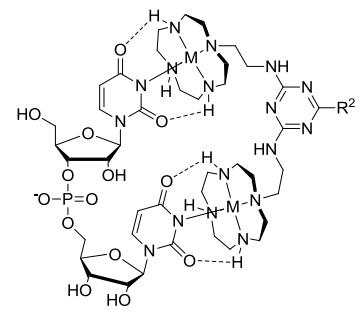

UpU : 2i $\left(R^{2}=2-\left(1 H\right.\right.$-imidazol-4-yl)ethylamino, $\left.M=Z^{2+}\right)$ UpU : 2 n $\left(R^{2}=\mathrm{NHMe}, \mathrm{M}=\mathrm{Zn}^{2+}\right)$ $\mathrm{UpU}: 20\left(\mathrm{R}^{2}=\mathrm{OMe}, \mathrm{M}=\mathrm{Zn}^{2+}\right)$
UpU : $2 \mathbf{h}\left(R^{2}=\mathrm{H}, \mathrm{M}=\mathrm{Zn}^{2+}\right)$

Fig. 1 Complexes of UpU with bi- and trinuclear $\mathrm{Zn}^{\mathrm{II}}$ chelates of 1,5,9$50 \quad$ trizazcyclododecane ( $\mathbf{1 a}$ and $\mathbf{1 b})$ and cyclen ( $\mathbf{2 h}, \mathbf{2 i}, \mathbf{2 n}$ and $\mathbf{2 0})$.

allows the uncatalyzed cleavage of $\mathrm{UpU}$ to proceed at an unaltered rate. The third $\mathrm{Zn}^{\mathrm{II}}$ :azacrown unit of 1a operates as a catalytic center, promoting the hydrolysis of UpU 100-fold compared to the corresponding monomeric compound. ${ }^{5}$ In other 55 words, even though the bi- and trinuclear $\mathrm{Zn}^{\mathrm{II}}$ :azacrown compounds bind tightly with $\mathrm{UpU}$, they still allow the cleavage of its phosphodiester bond to take place.

In the new scaffolds ( $\mathbf{2 h}, \mathbf{2} \mathbf{i}, \mathbf{2 n}$ and $\mathbf{2 0}$ ) employed in the present work, the two UpU anchoring $\mathrm{Zn}^{\mathrm{II}}$ :cyclen chelates are ${ }_{60}$ linked to a common 1,3,5-triazine core instead of the benzene core applied in $\mathbf{1 b}$. The former has potential to function as a "shuttle" mediating proton transfer from the attacking 2'-hydroxy function to a non-bridging oxygen of the phosphorane intermediate and, finally, to the leaving group. A similar ${ }_{65}$ mechanism has been proposed for catalysis by the hammerhead and hairpin ribozymes, with a guanine base transferring a proton from the attacking $2^{\prime}$-oxygen to the pro- $R_{\mathrm{P}}$ non-bridging phosphoryl oxygen. ${ }^{6}$ It should be noted that the $\mathrm{Zn}^{\text {II }}$ chelate of cyclen is a poorer catalyst for phosphodiester cleavage than the 


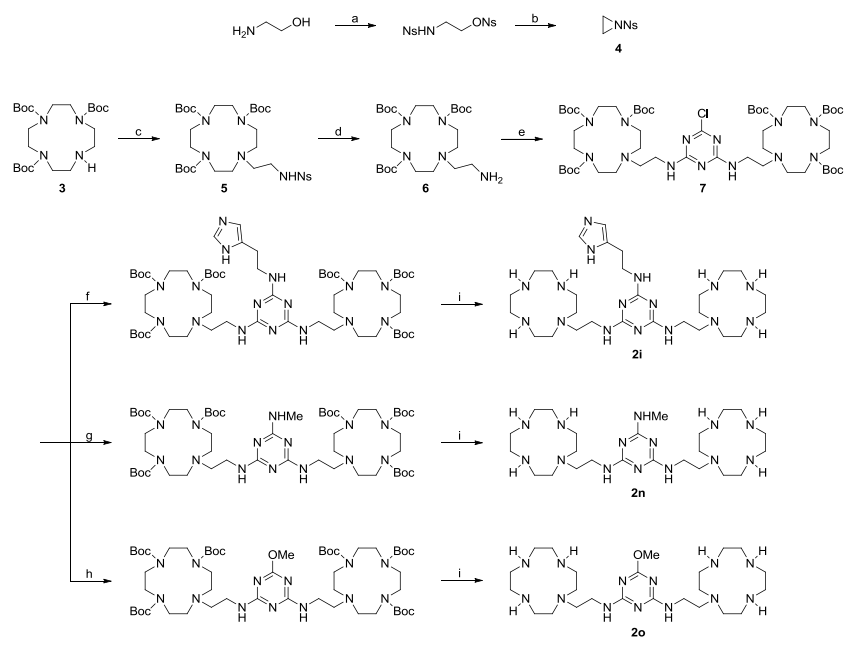

Scheme 1 Preparation of the cleaving agents $2 \mathbf{i}, 2 \mathrm{n}$ and $2 \mathbf{2 o}$. Reagents and conditions: (a) 4-nitrobenzenesulfonyl chloride, pyridine, $\mathrm{CH}_{2} \mathrm{Cl}_{2}$, (b)

$5 \mathrm{KOH}, \mathrm{H}_{2} \mathrm{O}, \mathrm{CH}_{2} \mathrm{Cl}_{2}$, (c) 4, MeCN, (d) thioglycolic acid, DBU, DMF, (e) cyanuric chloride, DIPEA, MeCN, (f) histamine, DIPEA, MeCN, (g) methylamine, EtOH, (h) $\mathrm{NaOMe}, \mathrm{MeOH}$, (i) TFA, $\mathrm{CH}_{2} \mathrm{Cl}_{2}, \mathrm{MeOH}$.

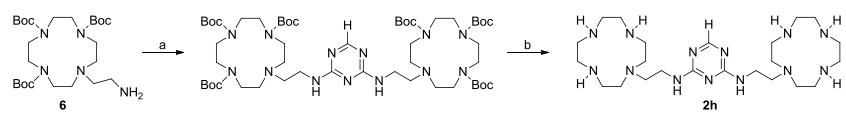

10

Scheme 2 Preparation of the cleaving agent $2 \mathbf{h}$. Reagents and conditions: (a) 2,4-dichlorotriazine, DIPEA, MeCN, (b) TFA, $\mathrm{CH}_{2} \mathrm{Cl}_{2}, \mathrm{MeOH}$.

$\mathrm{Zn}^{\mathrm{II}}$ chelate of the previously used 1,5,9-triazacyclododecane. ${ }^{7}$ It is, hence, expected that the cyclen moieties are only engaged in 15 binding with the uracil bases and are catalytically inactive (Fig.

1). Four different cleaving agents were prepared, differing only in the substituent at position 6 of the triazine ring. In compounds $\mathbf{2 h}$, 2n and 2o, the role of this substituent is simply to adjust the $\mathrm{p} K_{\mathrm{a}}$ value of the triazine core, whereas the histamine sidearm of $2 \mathbf{i}$ has 20 the potential to function as a general acid/base catalyst on its own.

\section{Results and discussion}

\section{Preparation of the cleaving agents}

Synthesis of the 1,3,5-triazine-based cleaving agents $\mathbf{2 i}, \mathbf{2 n}$ and ${ }_{25} \mathbf{2 0}$ is presented in Scheme 1. First, a 2-aminoethyl sidearm was attached to the free secondary amino function of $N^{4}, N^{7}, N^{10}$-tritert-butoxycarbonylcyclen $\left(\mathbf{3}^{8}\right.$ by ring-opening of $\mathrm{N}-4$ nitrobenzenesulfonylaziridine (4), prepared from ethanolamine as previously described for several other aminoalcohols. ${ }^{9}$ ${ }_{30}$ Subsequent removal of the 4-nitrobenzenesulfonyl group afforded Boc-protected aminoethyl-functionalized cyclen (6) which was used to displace two of the chloro substituents of cyanuric chloride, giving the protected non-substituted scaffold (7). Finally, the last chloride was displaced by histamine, 35 methylamine or methanol, the Boc protections were removed and the products were converted to free amines $(\mathbf{2} \mathbf{i}, \mathbf{2 n}$ and $\mathbf{2 o}$, respectively) by passing them through an $\mathrm{OH}^{-}$-form strong cation exchange resin. In the synthesis of $\mathbf{2 h}, 2,4$-dichlorotriazine was used instead of cyanuric chloride and the product thus obtained

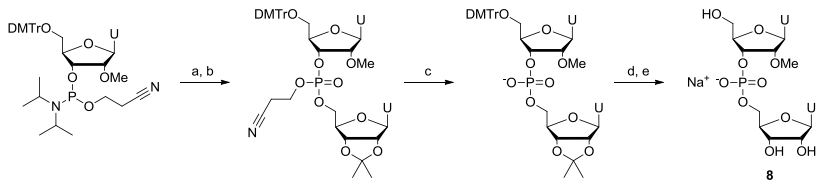

Scheme 3 Preparation of 2'-O-methyluridylyl-3',5'-uridine $(\mathbf{8}, \mathbf{m U p U})$. Reagents and conditions: (a) 2',3'-O-isopropylideneuridine, $1 \mathrm{H}$-tetrazole, MeCN, (b) $\mathrm{I}_{2}$, 2,6-lutidine, THF, $\mathrm{H}_{2} \mathrm{O}$, (c) $\mathrm{NH}_{3}, \mathrm{MeOH}$, (d) $\mathrm{HCl}, \mathrm{H}_{2} \mathrm{O}$, (e) Dowex 50Wx8 $\left(\mathrm{Na}^{+}\right), \mathrm{H}_{2} \mathrm{O}$.

45 was deprotected and passed through an $\mathrm{OH}^{-}$-form strong cation exchange resin to yield $\mathbf{2 h}$ as the free amine (Scheme 2).

Preparation of $2^{\prime}-O$-methyluridylyl-3',5'-uridine

For a nonreactive UpU mimic to be used as a target when determining the stability of the complexes, $2^{\prime}$ - $O$-methyluridylyl$503^{\prime}, 5^{\prime}$-uridine (8) was prepared by tetrazole-promoted coupling of commercially available $55^{\prime}-O-\left(4,4^{\prime}\right.$-dimethoxytrityl)-2' $-O$ methyluridine-3'-(2-cyanoethyl)- $N, N$ -

diisopropylphosphoramidite and $2^{\prime}, 3^{\prime}$ - $O$-isopropylideneuridine (Scheme 3). Removal of the cyanoethyl, dimethoxytrityl and 55 isopropylidene protections and subsequent treatment with $\mathrm{Na}^{+}-$ form strong cation exchange resin afforded $\mathbf{8}$ as the sodium salt.

Determination of the stability of the complexes by potentiometric and spectrophotometric titrations

In order to have thermodynamic data on the interaction between ${ }_{60} \mathrm{Zn}^{\mathrm{II}}$ and the 1,3,5-triazine-based ligands, as well as between UpU and the binuclear $\mathrm{Zn}^{\mathrm{II}}$ complexes, we have studied the protonation of $\mathbf{8}(\mathbf{m U p U})$ and $\mathbf{2 n}(\mathbf{L})$, the complex formation in the $\mathrm{Zn}^{\mathrm{II}}: \mathbf{L}, \mathrm{Zn}^{\mathrm{II}}: \mathbf{m U p U}$ binary, and in the $\mathrm{Zn}^{\mathrm{II}}: \mathbf{m U p U}-\mathbf{L}$ ternary systems. The determined formation constants and derived data for 65 the relevant equilibria are listed in Table 1 . The species distribution curves of the $\mathrm{Zn}^{\mathrm{II}}: \mathbf{L}(-\mathbf{m U} \mathbf{p U})$ systems are depicted in Fig. 2.

The protonation constants of $\mathbf{m U p U}(\mathbf{8})$ are almost identical with those of UpU. ${ }^{10}$ Since the interaction of $\mathrm{Zn}^{\mathrm{II}}$ with $\mathbf{m U p U}$ is rather weak, slight hydrolysis of $\mathrm{Zn}^{\mathrm{II}}$ was observed above $\mathrm{pH} 8.5$ 70 in the $\mathrm{Zn}^{\mathrm{II}}: \mathbf{m U p U}$ system. Therefore only the data below $\mathrm{pH} 8.5$ were considered during our evaluation, and the hydroxo complexes of $\mathrm{Zn}^{\mathrm{II}}$ were taken into account. ${ }^{11}$ Under these conditions the formation of two binary complexes was detected. In $\mathrm{Zn}(\mathrm{HmU} \mathbf{U} \mathbf{U})$ the metal ion is very likely coordinated to one of 75 the uracil-N3 nitrogen atom. Its deprotonation $(\mathrm{p} K=8.08)$ is probably related to the formation of a mixed hydroxo species $(\mathrm{Zn}(\mathrm{HmU} \mathbf{p U})(\mathrm{OH}))$.

Over the studied $\mathrm{pH}$ range, five protonation steps of $\mathbf{L}$ (2n) can be observed (Table 1). At $\mathrm{pH} 7$ both cyclen rings are doubly 80 protonated. The first two and the second two protonation constants show the expected statistical differences $(\sim 0.9)$, and their average (10.77 and 8.59) agrees well with the protonation constants of $\mathrm{N}$-alkyl mono-substituted cyclens. ${ }^{12}$ The fifth protonation is related to the 1,3,5-triazine ring.

85 At first sight, the speciation diagrams in Figure 2 show a complicated picture, however, the composition of the formed species are, in fact, rather obvious. The presence of two azacrowns allow the formation of mono- and dinuclear complexes, and due the acid-base properties of the non-bonded 90 nitrogens and coordinated water molecules, both may have several different protonation states (an example illustrating the excellence of the fits of the potentiometric data is included as 

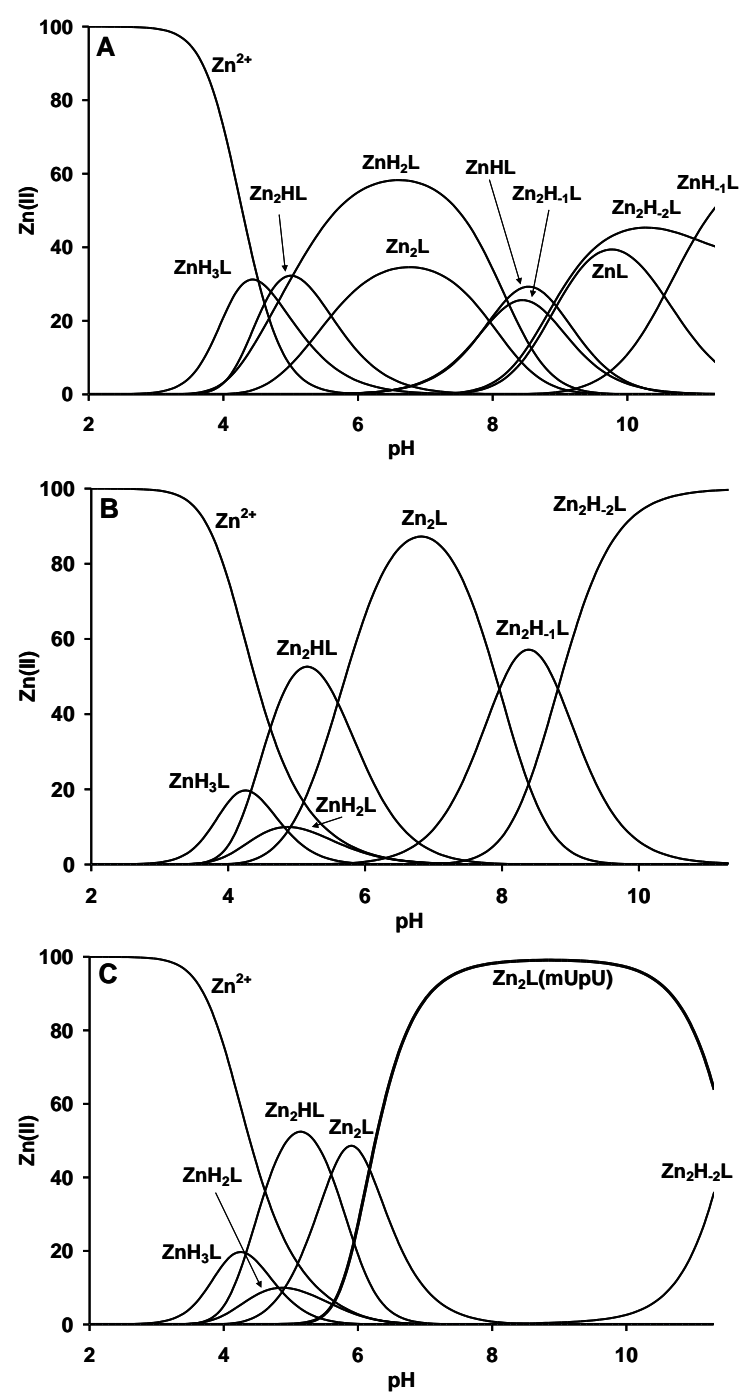

Fig. 2 Species distribution curves for the $\mathrm{Zn}^{\mathrm{II}}$ complexes in the $\mathrm{Zn}^{\mathrm{II}} / \mathbf{L}$ / $\mathbf{m U p U}=1 / 1 / 0(\mathrm{~A}), 2 / 1 / 0(\mathrm{~B})$ and $2 / 1 / 1(\mathrm{C})$ systems $\left(T=25^{\circ} \mathrm{C}, I(\mathrm{NaCl})\right.$ $\left.=0.1 \mathrm{~mol} \mathrm{~L}^{-1},[\mathbf{L}]=1 \mathrm{mmol} \mathrm{L}^{-1}\right)$.

5 supporting information). In the protonated mononuclear $\mathrm{Zn}^{\mathrm{II}}$ complexes the metal ion is coordinated to one of the macrocyclic units, while the other one, and the 1,3,5-triazine ring in $\mathrm{ZnH}_{3} \mathbf{L}$, is protonated. This is supported by the almost identical $\log K$ values related to $\mathrm{Zn}^{\mathrm{II}}$ binding to the tri-, di- and mono-protonated ligand $10\left(\log K_{3}, \log K_{4}\right.$ and $\log K_{5}$ in Table 1$)$.

Although, Kimura and his coworkers reported a number of equilibrium studies on $\mathrm{Zn}_{2}$-bis(cyclen) complexes related to the equilibria $\mathrm{Zn}_{2} \mathrm{~L}+\mathrm{X}=\mathrm{Zn}_{2} \mathrm{LX}$ (where $\mathrm{X}=\mathrm{OH}^{-}$, 1-methylthymine, $\mathrm{TpT}$ etc. $)^{4,13,14}$, to our knowledge only a single paper reports 15 complete solution equilibrium study on the formation of binary $\mathrm{Zn}$ (II) complexes of bis-cyclen derivatives. ${ }^{15}$ However, the ligands reported in ref. 15 contained 1,4-phenylene spacers, and the macrocyclic units possessed aminoalkyl pendant arms, which may also coordinate to the metal ions. As a consequence, latter 20 ligands provided two separated binding sites for the metal ions. In contrast, the relatively large difference between the binding constants of the first and second metal ion to $\mathbf{L}\left(\log K_{6}\right.$ and $\log K_{10}$ in Table $1, \Delta \log K=5.4$ ) may indicate the weak binding of the second cyclen ring to the metal ion in $\mathrm{ZnL}$, too. Such 'earmuff'
25 Table 1 Formation constants $\left(\log \beta_{\text {pqrs }}\right)$ and some derived equilibrium data of the $\mathrm{Zn}^{\mathrm{II}}$ complexes of $\mathbf{8}(\mathbf{m U p U})$ and $2 \mathbf{n}(\mathbf{L})(I=0.1 \mathrm{M} \mathrm{NaCl}, T=298$ $\mathrm{K}){ }^{a}$

\begin{tabular}{lclc}
\hline \multicolumn{1}{c}{$\operatorname{pqrs}^{b}$ (species) } & \multicolumn{1}{c}{$\log \beta_{\text {pqrs }}$} & \multicolumn{1}{c}{$\operatorname{pqrs}^{\mathbf{b}}($ species $)$} & $\log \beta$ pqrs \\
$1101(\mathrm{Zn}(\mathrm{HmU} \mathbf{})$ & $13.12 \pm 0.09$ & $1-110(\mathrm{ZnL}(\mathrm{OH})$ & $5.24 \pm 0.06$ \\
$1001(\mathrm{ZnHmUpU}(\mathrm{OH}))$ & $5.04 \pm 0.09$ & $2110\left(\mathrm{Zn}_{2} \mathrm{HL}\right)$ & $31.76 \pm 0.05$ \\
$1310\left(\mathrm{ZnH}_{3} \mathbf{L}\right)$ & $37.75 \pm 0.05$ & $2010\left(\mathrm{Zn}_{2} \mathbf{L}\right)$ & $26.16 \pm 0.05$ \\
$1210\left(\mathrm{ZnH}_{2} \mathbf{L}\right)$ & $32.94 \pm 0.05$ & $2-110\left(\mathrm{Zn}_{2} \mathbf{L}(\mathrm{OH})\right)$ & $18.19 \pm 0.06$ \\
$1110\left(\mathrm{ZnH}_{2} \mathbf{L}(\mathrm{OH})^{c}\right)$ & $24.73 \pm 0.06$ & $2-210\left(\mathrm{Zn}{ }_{2} \mathbf{L}(\mathrm{OH}) 2\right)$ & $9.38 \pm 0.06$ \\
$1010\left(\mathrm{ZnHL}(\mathrm{OH})^{\mathrm{c}}\right)$ & $15.78 \pm 0.06$ & $2011\left(\mathrm{Zn}_{2} \mathbf{L}(\mathbf{m U p U})\right)$ & $35.70 \pm 0.03$
\end{tabular}

Derived data for relevant equilibria

$\log K_{1}\left(\mathrm{Zn}^{2+}+\mathrm{HmUpU}=\mathrm{Zn}(\mathrm{HmUpU})\right)=3.80$

$\log K_{2}\left(\mathrm{Zn}(\mathrm{HmUpU})+\mathrm{OH}^{-}=\mathrm{Zn}(\mathrm{HmU} \mathbf{p U})(\mathrm{OH})\right)=5.67$

$\log K_{3}\left(\mathrm{Zn}^{2+}+\mathrm{H}_{3} \mathbf{L}=\mathrm{ZnH}_{3} \mathbf{L}\right)=14.10^{\mathrm{d}}$

$\log K_{4}\left(\mathrm{Zn}^{2+}+\mathrm{H}_{2} \mathbf{L}=\mathrm{ZnH}_{2} \mathbf{L}\right)=13.58^{\mathrm{d}}$

$\log K_{5}\left(\mathrm{Zn}^{2+}+\mathrm{HL}=\mathrm{ZnHL}\right)=13.96^{\mathrm{d}}$

$\log K_{6}\left(\mathrm{Zn}^{2+}+\mathbf{L}=\mathrm{ZnL}\right)=15.78$

$\log K_{7}\left(\mathrm{ZnH}_{2} \mathbf{L}+\mathrm{OH}^{-}=\mathrm{ZnH}_{2} \mathbf{L}(\mathrm{OH})\right)=5.54$

$\mathrm{p} K_{8}\left(\mathrm{ZnH}_{2} \mathbf{L}(\mathrm{OH})=\mathrm{ZnHL}(\mathrm{OH})+\mathrm{H}^{+}\right)=8.95$

$\mathrm{p} K_{9}\left(\mathrm{ZnHL}(\mathrm{OH})=\mathrm{ZnL}(\mathrm{OH})+\mathrm{H}^{+}\right)=10.54$

$\log K_{10}\left(\mathrm{ZnL}+\mathrm{Zn}^{2+}=\mathrm{Zn}_{2} \mathbf{L}\right)=10.38$

$\log K_{11}\left(\mathrm{ZnL}(\mathrm{OH})+\mathrm{Zn}^{2+}=\mathrm{Zn}_{2} \mathbf{L}(\mathrm{OH})\right)=12.95$

$\log K_{12}\left(\mathrm{Zn}_{2} \mathbf{L}+\mathrm{OH}^{-}=\mathrm{Zn}_{2} \mathbf{L}(\mathrm{OH})\right)=5.78$

$\log K_{13}\left(\mathrm{Zn}_{2} \mathbf{L}(\mathrm{OH})+\mathrm{OH}^{-}=\mathrm{Zn}_{2} \mathbf{L}(\mathrm{OH})_{2}\right)=4.94$

$\log K_{14}\left(\mathrm{Zn}_{2} \mathbf{L}+\mathbf{m U p U}=\mathrm{Zn}_{2} \mathbf{L}(\mathbf{m U} \mathbf{p U})\right)=9.54$

$\log K_{15}\left(\mathrm{Zn}_{2} \mathrm{~L}+\mathrm{H}_{2} \mathbf{m U} \mathbf{p U}=\mathrm{Zn}_{2} \mathrm{~L}(\mathbf{m U p U})+2 \mathrm{H}^{+}\right)=-9.11\left(-7.94\right.$ at $\left.90^{\circ} \mathrm{C}\right)$

${ }^{a}$ The protonation constants of $\mathbf{m U p U}$ and $\mathbf{L}$ are $\log \beta_{0101}=9.74 \pm 0.02$, $\log \beta_{0201}=18.65 \pm 0.02$, and $\log \beta_{0110}=11.25 \pm 0.04, \log \beta_{0210}=21.53 \pm$ $300.04, \log \beta_{0310}=30.55 \pm 0.04, \log \beta_{0410}=38.70 \pm 0.04, \log \beta_{0510}=42.99 \pm$ 0.04 , respectively. ${ }^{b} \mathrm{p}, \mathrm{q}, \mathrm{r}$ and $\mathrm{s}$ are the stoichiometric coefficients for $\mathrm{Zn}^{\mathrm{II}}, \mathrm{H}^{+}, \mathbf{L}(\mathbf{2 n})$ and $\mathbf{m U p U}(\mathbf{8})$, respectively. ${ }^{\mathrm{c}}$ main species, other protonation isomers may also exist. ${ }^{\mathrm{d}}$ the following values were used for the pKs of non zinc-bounded cyclen ring: $\log \beta_{0210} / 2=10.77$ and $\left(\log \beta_{0410}\right.$ $\left.35-\log \beta_{0210}\right) / 2=8.59$

-like coordination is highly stable for some bis(1,4,7-triazacyclononane) derivatives. ${ }^{16}$ Although, the relatively rigid 2,4substituted triazine spacer would prefer the formation of similar structure in the present case, even its partial formation is rather 40 surprising considering the tetradentate nature of cyclen ring.

In the absence of aminoalkyl pendant arms, the metal ions in the dinuclear $\mathrm{Zn}_{2} \mathbf{L}$ species are stronger Lewis acids than those reported in ref 15 , therefore the deprotonation of metal bound water molecules take place at c.a. 2 units lower pH. The $\Delta \log K=$ ${ }_{45} \log K_{12}-\log K_{13}=0.84$ value corresponds to the statistical difference, and thus indicates no interaction between the two metal centers in the dinuclear monohydroxo species $\left(\mathrm{Zn}_{2} \mathbf{L}(\mathrm{OH})\right)$.

In equimolar solutions of $\mathrm{Zn}^{\mathrm{II}}$ and $\mathbf{L}$, considerable amounts of binuclear complexes are present (Fig. 2A). This is the 50 consequence of the two identical binding sites in $\mathbf{L}$, since under such conditions statistical considerations predict nearly equal amounts of ligand bound in mono- and binuclear complexes.

In the $\mathrm{Zn}^{\mathrm{II}}$ :L:mUpU system our potentiometric study indicated the formation of a single very stable ternary complex ${ }_{55}\left(\mathrm{Zn}_{2} \mathbf{L}(\mathbf{m U p U})\right)$, which is the sole species over a wide $\mathrm{pH}$-range 
(Fig. 2C). mUpU fits into the scaffold created by the $\mathrm{Zn}_{2} \mathbf{L}$ complex almost ideally, since the value of $\log K_{14}$ (=9.54 for the reaction $\mathrm{Zn}_{2} \mathbf{L}+\mathbf{m U p U}=\mathrm{Zn}_{2} \mathbf{L}(\mathbf{m U p U})$ ) is nearly twice as high as the respective constant for the process $\mathrm{Zn}$ :cyclen + uridine $=$ Zn:cyclen(uridine), $\log K=5.2 .^{13}$

The $\mathrm{Zn}_{2} \mathbf{L}-\mathbf{m U p U}$ interaction has also been studied by UVspectrophotometric titrations both at $25^{\circ} \mathrm{C}$ and $90^{\circ} \mathrm{C}$ (Fig. 3 and 4). The decrease in the UV absorbance of $\mathbf{m U p U}$ at $260 \mathrm{~nm}$ upon addition of the $\mathrm{Zn}_{2} \mathbf{L}$ complex at $25^{\circ} \mathrm{C}$ and $\mathrm{pH} 8.8$ results from the 10 binding of the dinuclear species to the base moieties of $\mathbf{m U p U}$ (Fig. 3). The spectrophotometric data depicted in Fig. 3 have been quantitatively evaluated in two different ways. Taking into account the formation constants determined by potentiometry for the binary complexes, the spectrophotometric data allowed the 15 calculation of the formation constant of the ternary species $\log \beta_{2011}=35.37 \pm 0.06$, which agrees well with the value determined by potentiometric measurements (see Table 1). Furthermore, we also calculated an apparent stability constant for the $\mathrm{Zn}_{2} \mathrm{H}_{\mathrm{x}} \mathbf{L}+\mathrm{H}_{\mathrm{x}} \mathbf{m U \mathbf { p } U}=\mathrm{Zn}_{2} \mathbf{L}(\mathbf{m U} \mathbf{p} \mathbf{U})$ reaction ( $\log K_{\text {app }}=$ 20 5.98(3)), which can be directly compared to the value determined

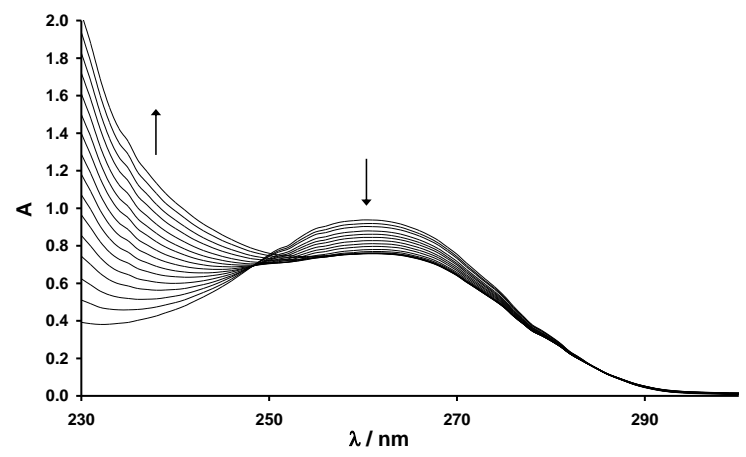

Fig. 3 UV-absorption spectrum of $\mathbf{m U p U}\left(55 \mu \mathrm{mol} \mathrm{L} \mathrm{L}^{-1}\right.$ aqueous solution) titrated with a solution that contained $\mathrm{Zn}^{\mathrm{II}}$ and $\mathbf{L}$ in a $2: 1$ ratio $\left([\mathbf{L}]_{\mathrm{tot}}=1.55\right.$ $\left.\mathrm{mmol} \mathrm{L}^{-1}\right)$ at $\mathrm{pH} 8.9\left(T=25^{\circ} \mathrm{C}, I(\mathrm{NaCl})=0.1 \mathrm{~mol} \mathrm{~L}^{-1}\right)$.

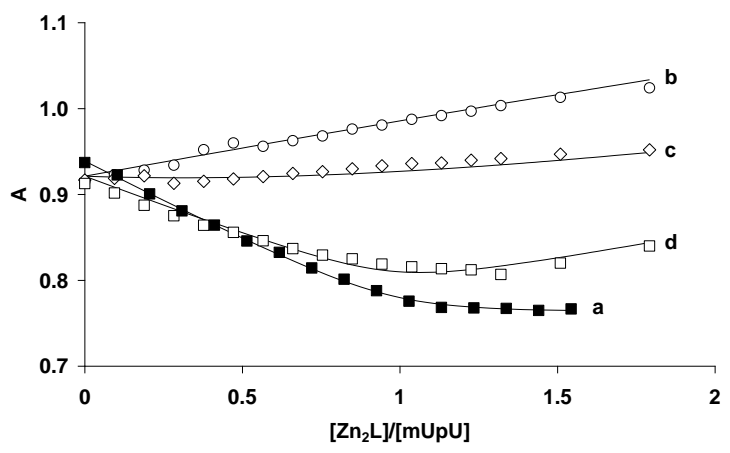

Fig. 4 UV spectrophotometric titration $(260 \mathrm{~nm})$ of $\mathbf{m U p U}\left(55 \mu \mathrm{mol} \mathrm{L} \mathrm{L}^{-1}\right)$ with a solution that contained $\mathrm{Zn}^{\mathrm{II}}$ and $\mathbf{L}$ in a $2: 1$ ratio $\left([\mathbf{L}]_{\mathrm{tot}}=1.55 \mathrm{mmol}\right.$ $\left.\mathrm{L}^{-1}\right)$ at $\mathrm{pH}=8.9, T=25^{\circ} \mathrm{C}(\mathbf{a}, \mathbf{\square}), \mathrm{pH}^{*}=5.0, T=90^{\circ} \mathrm{C}(\mathbf{b}, \bigcirc), \mathrm{pH}^{*}=$ $6.0, T=90^{\circ} \mathrm{C}(\mathbf{c}, \diamond)$ and $\mathrm{pH}^{*}=7.0, T=90^{\circ} \mathrm{C}(\mathbf{d}, \square)(I(\mathrm{NaCl})=0.1 \mathrm{~mol}$ 30 $\left.\mathrm{L}^{-1}\right)$.

at $90{ }^{\circ} \mathrm{C}$ (see later). The measured and calculated absorbances at $260 \mathrm{~nm}$ are shown in Fig. 4 (curve a).

In order to have quantitative date on the stability of the ternary $\mathrm{Zn}_{2} \mathbf{L}(\mathbf{m U p U})$ complex at the temperature used for the kinetic 35 measurements, we performed UV-spectrophotometric titrations between $\mathrm{pH}^{*}=5-7$ at $90{ }^{\circ} \mathrm{C}$. The UV-titrations made at several
$\mathrm{pH}^{*}$ allowed us to follow the $\mathrm{Zn}_{2} \mathbf{L}+\mathrm{H}_{2} \mathbf{m U} \mathbf{p U}=\mathrm{Zn}_{2} \mathbf{L}(\mathbf{m U p U})+$ $2 \mathrm{H}^{+}$reaction (Figure 4 , curve b-d). At $\mathrm{pH}^{*}=5$ (Figure 4 , curve b) the formation of the ternary species is negligible, therefore 40 curve $b$ reflects the increasing amount of the binary $\mathrm{Zn}_{2} \mathbf{L}$ species (which also absorbs at $262 \mathrm{~nm}$ at this temperature). On the other hand, at $\mathrm{pH}^{*} 7$ (curve d) the majority of the added $\mathrm{Zn}_{2} \mathrm{~L}$ complex transforms into the ternary species until a 1:1 ratio of $\mathrm{Zn}_{2} \mathbf{L}$ and $\mathbf{m U p U}$ is reached. These data indicate the formation of the ${ }_{45} \mathrm{Zn}_{2} \mathbf{L}(\mathbf{m U p U})$ ternary complex also at $90{ }^{\circ} \mathrm{C}$. The equilibrium constant determined for the above reaction at $90{ }^{\circ} \mathrm{C}$ is $\log K_{15}=-$ $7.94 \pm 0.06$. The corresponding constant at $25^{\circ} \mathrm{C}$ is $\log K_{15}=-$ 9.11, which indicates that with increasing temperature the formation of the ternary complex shifts to a lower $\mathrm{pH}$-range. At ${ }_{50} \mathrm{pH}^{*}=7$ we also calculated the apparent stability constants for the $\mathrm{Zn}_{2} \mathrm{H}_{\mathrm{x}} \mathbf{L}+\mathrm{H}_{\mathrm{x}} \mathbf{m U} \mathbf{p} \mathbf{U}=\mathrm{Zn}_{2} \mathbf{L}(\mathbf{m} \mathbf{U} \mathbf{\mathbf { U }})$ reaction $\left(\log K_{\text {app }}=5.10 \pm\right.$ 0.08). The latter value shows tight binding of $\mathrm{Zn}_{2} \mathbf{L}$ to $\mathbf{m U p U}$ even at this higher temperature.

\section{Reaction pathways and product distribution}

${ }_{55}$ Hydrolytic reactions of UpU were followed at $90{ }^{\circ} \mathrm{C}$ over a $\mathrm{pH}^{*}$ range of $3.52-10.21$ in the presence of a 12-fold excess of the

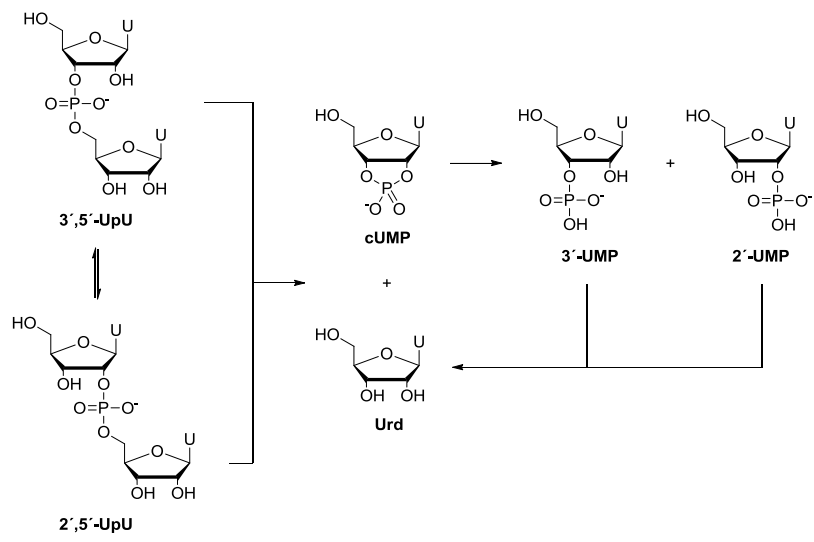

Scheme 4 Hydrolytic reaction pathways of UpU.

cleaving agent and at $\mathrm{pH}^{*} 7.42$ as a function of the concentration ${ }_{60}$ of the cleaving agent or UpU by analyzing the composition of the aliquots withdrawn from the reaction mixture at appropriate time intervals by RP HPLC. In all cases, 2 eq. of $\mathrm{Zn}\left(\mathrm{NO}_{3}\right)_{2}$ relative to the cleaving agent were used. The reactions were started by mixing a small amount of the UpU stock solution with the 65 reaction buffer prethermostated to $90{ }^{\circ} \mathrm{C}$ to give the desired UpU concentration and quenched by cooling the aliquots to $0{ }^{\circ} \mathrm{C}$. The products were characterized by spiking with authentic samples.

Over the entire $\mathrm{pH}^{*}$ range studied and regardless of whether the cleaving agent is present in excess or not, the same product 70 distribution is observed (Scheme 4). Disappearance of UpU is accompanied by formation of uridine and comparable amounts of uridine $2^{\prime}$ - and $3^{\prime}$-monophosphates. Only traces of the initially formed uridine $2^{\prime}, 3^{\prime}$-cyclic monophosphate are detected, owing to its rapid hydrolysis to the $2^{\prime}$ - and $3^{\prime}$-monophosphates. Below $75 \mathrm{pH}^{*} 8$, mutual isomerization of $3^{\prime}, 5^{\prime}-$ and $2^{\prime}, 5^{\prime}-\mathrm{UpU}$ is also observed.

For the experiments carried out in the presence of an excess of the cleaving agent, pseudo first-order rate constants for the disappearance of UpU were obtained by applying the integrated 80 first-order rate law to the time-dependent diminution of the 
relative peak area of $\mathrm{UpU}$. When the reaction rate was studied as a function of UpU concentration at a constant limiting concentration of the cleaving agent, initial rates were obtained as slopes of the plots of the combined peak area of all the 5 monomeric products $\left(2^{\prime}, 3^{\prime}\right.$-cUMP, $3^{\prime}$-UMP, $2^{\prime}$-UMP and uridine) as a function of reaction time.

\section{Dependence of rate on cleaving agent concentration}

To verify the catalytic activity of the binuclear $\mathrm{Zn}^{\mathrm{II}}$ :cyclen compounds synthesized, cleavage of UpU was followed at 10 various concentrations $\left(0-80 \mu \mathrm{mol} \mathrm{L} \mathrm{L}^{-1}\right)$ of the methylamino derivative $2 \mathbf{n}\left(T=90{ }^{\circ} \mathrm{C} ; \mathrm{pH}^{*}=6.57\right)$. Cleavage of ApA was followed under the same conditions for comparison. The dependence of the observed pseudo first-order rate constant for the cleavage of UpU and ApA as a function of [2n] is presented 15 in Fig. 5.

Cleavage of UpU follows simple first-order kinetics and attains a rate acceleration of nearly two orders of magnitude at sufficiently high concentrations of the dizinc complex of $\mathbf{2 n}$. The observed first-order rate constant for the reaction may be 20 expressed by eqn. (1).

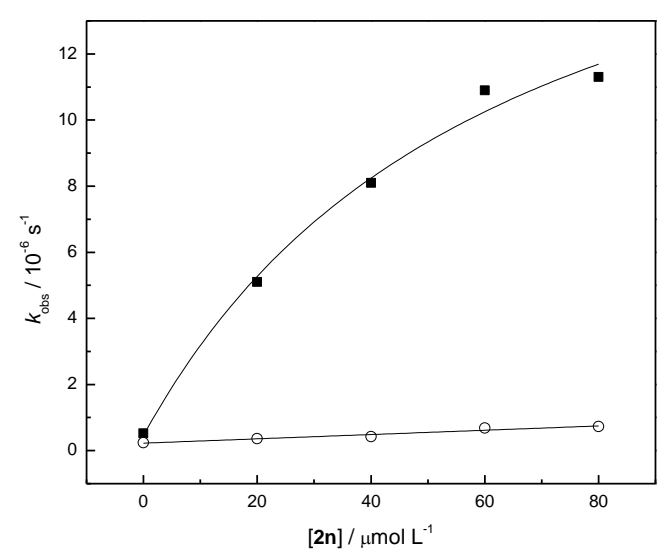

Fig. 5. Pseudo first-order rate constants for the cleavage of $U p U(\boldsymbol{\square})$ and $25 \mathrm{ApA}(\mathrm{O})$ as a function of the concentration of the cleaving agent $\mathbf{2 n}$ at 90 ${ }^{\circ} \mathrm{C}, \mathrm{pH}^{*}=6.57, I\left(\mathrm{NaClO}_{4}\right)=0.10 \mathrm{~mol} \mathrm{~L}^{-1},[\mathrm{UpU}]=[\mathrm{ApA}]=5.0 \mu \mathrm{mol} \mathrm{L}$

$$
k_{\text {obs }}=k_{\text {uncat }}+k_{\text {cat }} \frac{[\mathbf{2 n}]}{K_{d}+[\mathbf{2 n}]}
$$

30

$k_{\text {uncat }}$ and $k_{\text {cat }}$ are the first-order rate constants for the spontaneous and 2n-catalyzed hydrolysis, respectively, and $K_{\mathrm{d}}$ is the dissociation constant for the complex between $\mathrm{UpU}$ and $\mathbf{2 n}: 2 \mathrm{Zn}^{\mathrm{II}}$. The observed dissociation constant is $\log K_{\mathrm{d}}=-4.2 \pm 0.2$, in 35 reasonable agreement with the corresponding value obtained by spectrophotometric titrations at $\mathrm{pH}^{*} 7$, taking into account the difference in $\mathrm{pH}^{*}\left(\log K_{\mathrm{d}}=-\log K_{\mathrm{app}}=-5.1\right)$. In contrast to the cleavage of UpU, cleavage of ApA is hardly accelerated by $\mathbf{2 n}$, indicating that binding of the nucleobases to the $\mathrm{Zn}^{\mathrm{II}}$ :cyclen 40 moieties of the cleaving agent is essential for catalytic activity. In principle, one might argue that only one of the azacrown chelates is engaged in $\mathrm{UpU}$ binding, the other one serving as an intracomplex catalyst. The potentiometric studies, however, show that the complex having both of the cyclen moieties bound to ${ }_{45}$ uracil is overwhelmingly the most stable species. This finding is also consistent with the earlier observations of Kimura, according to which binding of 1,4-bis[(1,4,7,10-tetraazacyclododecan-1yl)methyl]benzene to $\mathrm{TpT}$ is much stronger than to 1methylthymine. ${ }^{14}$ Furthermore, it has been previously shown that 50 the related binuclear $\mathrm{Zn}^{\mathrm{II}}$ :azacrown complex $\mathbf{1 b}: 2 \mathrm{Zn}^{\mathrm{II}}$ does not catalyze the cleavage of $\mathrm{UpU}$, even though its $\mathrm{Zn}^{\mathrm{II}}: 1,5,9$ triazacyclododecane moieties are known to be better catalysts for phosphodiester cleavage than the $\mathrm{Zn}^{\mathrm{II}}$ :cyclen moieties of 2n: $2 \mathrm{Zn}^{\text {II }}$. ${ }^{\text {It }}$ seems, hence, extremely unlikely that the observed 55 rate acceleration by $\mathbf{2 n}$ would be due to metal ion catalysis. In all likelihood, the same conclusion holds also for the other cleaving agents $\mathbf{2 h}, \mathbf{2 i}$ and $\mathbf{2 0}$.

\section{Stoichiometry of the reactive complex}

The fact that the $\mathbf{2 n}$-catalyzed cleavage of UpU follows simple 60 first-order kinetics suggests 1:1 stoichiometry for the reactive UpU:2n complex. For more compelling evidence, a Job's plot

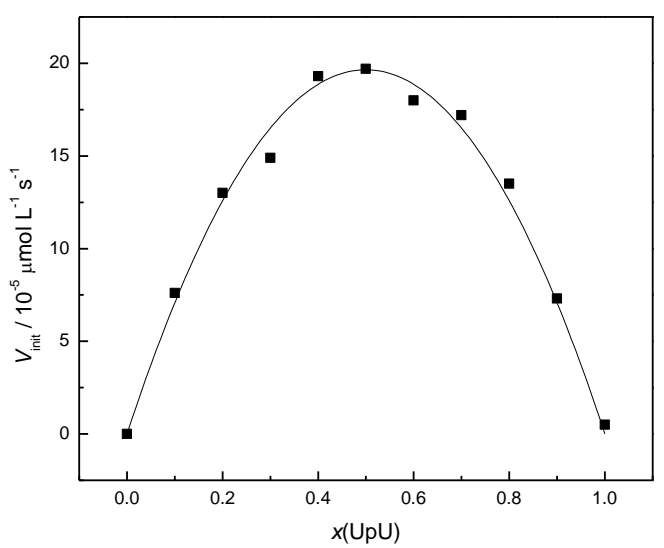

Fig. 6 Initial rate for the cleavage of $\mathrm{UpU}$ by $\mathbf{2 n}$ at $90{ }^{\circ} \mathrm{C}, \mathrm{pH}^{*}=$ $6.39, I\left(\mathrm{NaClO}_{4}\right)=0.10 \mathrm{~mol} \mathrm{~L}-1,[\mathrm{UpU}]+[\mathbf{2 n}]=50 \mu \mathrm{mol} \mathrm{L}^{-1}$.

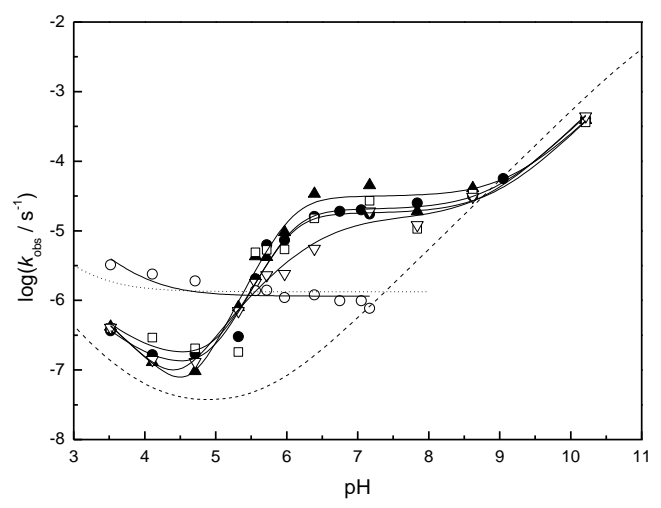

65

Fig. $7 \mathrm{pH}$-rate profiles for the cleavage of $\mathrm{UpU}$ in the absence (dashed line) and in the presence of the cleaving agents $2 \mathrm{~h}(\square), 2 \mathrm{i}(\nabla), 2 \mathrm{n}(\boldsymbol{O})$ and $2 \mathrm{o}(\boldsymbol{\Delta})$ and the isomerization of $\mathrm{UpU}$ in the absence (dotted line) and in the presence of $2 \mathrm{n}(\mathrm{O})$ at 70 
was constructed by measuring the initial rate of the cleavage of $\mathrm{UpU}$ at $\mathrm{pH}^{*} 6.39$ as a function of the mole fraction of $\mathbf{2 n}$, keeping the total concentration of $\mathrm{UpU}$ and $\mathbf{2 n}$ constant: [UpU] + [2n] $=50 \mu \mathrm{mol} \mathrm{L}{ }^{-1}$. The plot, presented in Fig. 6, has the shape of 5 a downward-opening parabola with a maximum at $x(\mathrm{UpU})=$ $x(\mathbf{2 n})=0.5$. As expected and also borne out by the titration studies with $\mathbf{2 n}$ and $\mathbf{8}$, one molecule of UpU binds to one molecule of $2 \mathbf{n}$ to form the reactive complex.

\section{pH-Rate profiles}

10 The $\mathrm{pH}$-rate profiles for the disappearance of UpU in the presence $\left(60 \mu \mathrm{mol} \mathrm{L} \mathrm{L}^{-1}\right)$ or absence ${ }^{17}$ of the cleaving agents are presented in Fig. 7. In the absence of any cleaving agents, cleavage of $\mathrm{UpU}$ becomes first-order in $\left[\mathrm{OH}^{-}\right]$at $\mathrm{pH}^{*} 6$ and remains so until quantitative deprotonation of the attacking 2 '15 hydroxy function is reached around $\mathrm{pH}^{*} 12.5 .{ }^{17}$ In contrast, in the presence of the cleaving agents, the reaction becomes roughly second-order in $\left[\mathrm{OH}^{-}\right]$at $\mathrm{pH}^{*} 4, \mathrm{pH}$-independent at $\mathrm{pH}^{*} 6$ and finally first-order in $\left[\mathrm{OH}^{-}\right]$at $\mathrm{pH}^{*} 8$. No data for the hydrolysis promoted by the cleaving agents $\mathbf{2 h}, \mathbf{2 i}, \mathbf{2 n}$ and $\mathbf{2 0}$ could be 20 obtained at $\mathrm{pH}^{*}<4$ owing to the instability of the $\mathrm{UpU}: 2 \mathrm{Zn}^{\mathrm{II}}: 2$

Table 2 Rate constants for the partial reactions of cleavage and isomerization of $U p U$ in the presence of the cleaving agents $2 \mathbf{h}, 2 \mathbf{i}, 2 \mathbf{n}$ and $2 \mathbf{o}\left(T=90{ }^{\circ} \mathrm{C}\right.$, $\left.I(\mathrm{NaClO})_{4}=0.10 \mathrm{~mol} \mathrm{~L}^{-1}\right)$.

$\begin{array}{lcccccc} & \mathbf{2 h}^{[\mathrm{a}]} & \mathbf{2 i}^{[\mathrm{a}]} & \mathbf{2 n}^{[\mathrm{a}]} & \mathbf{2 n}^{[\mathrm{b}]} & \mathbf{2 0}^{[\mathrm{a}]} & \begin{array}{c}\text { isom. with } \\ \mathbf{2 n}\end{array} \\ k_{1} / 10^{-4} \mathrm{~mol}^{-1} \mathrm{~L} \mathrm{~s}^{-1} & 10 \pm 10 & 14 \pm 6 & 9 \pm 5 & 11 \pm 6 & 14 \pm 5 & 90 \pm 30 \\ k_{2} / 10^{-7} \mathrm{~s}^{-1} & 1 \pm 1 & 0.2 \pm 0.7 & 0.9 \pm 0.5 & 0.5 \pm 0.6 & 0.1 \pm 0.4 & 12 \pm 1 \\ k_{3} / \mathrm{mol}^{-1} \mathrm{~L} \mathrm{~s}^{-1} & 0.3 \pm 0.1 & 0.26 \pm 0.06 & 0.34 \pm 0.06 & 0.35 \pm 0.05 & 0.5 \pm 0.1 & - \\ k_{4} / 10^{-2} \mathrm{~mol}^{-1} \mathrm{~L} \mathrm{~s}^{-1} & 4 \pm 3 & 4 \pm 1 & 4 \pm 1 & 4 \pm 2 & 3 \pm 1 & - \\ \mathrm{p} K_{\mathrm{a} 1}+\mathrm{p} K_{\mathrm{a} 2} & 12.2 \pm 0.4 & 11.4 \pm 0.7 & 12.2 \pm 0.1 & - & 12.16 \pm 0.2 & - \\ \mathrm{p} K_{\mathrm{a} 1} & - & 6.5 \pm 0.2 & - & - & - & - \\ \mathrm{p} K_{\mathrm{a} 2} & - & 4.9 \pm 0.5 & - & - & - & -\end{array}$

${ }^{a}$ Calculated using eqn. (2). ${ }^{b}$ Calculated using eqn. (3).

ternary complex under these conditions.Under the experimental 25 conditions, i.e. between $\mathrm{pH}^{*} 3.52$ and 10.21 , the observed rate constant for the cleavage of $\mathrm{UpU}, k_{\mathrm{cl}}{ }^{\text {obs }}$, may be expressed by eqn. (2).

$$
k_{o b s}^{c l}=k_{1}\left[\mathrm{H}^{+}\right]+k_{2}+\frac{k_{3}[2] K_{a 1} K_{a 2}}{\left[\mathrm{H}^{+}\right]^{2}+K_{a 1} K_{a 2}}+\frac{k_{4} K_{W}}{\left[\mathrm{H}^{+}\right]}
$$

$K_{\mathrm{a} 1}$ and $K_{\mathrm{a} 2}$ are the acidity constants of the two uracil bases (deprotonation of $\mathrm{N} 3$ upon complexation with $\mathrm{Zn}^{\mathrm{II}}$ :cyclen), [2] is the concentration of the cleaving agent used $\left(0\right.$ or $\left.60 \mu \mathrm{mol} \mathrm{L} \mathrm{L}^{-1}\right), k_{2}$ is the first-order rate constant for the $\mathrm{pH}$-independent cleavage of ${ }_{35} \mathrm{UpU}$ and $k_{1}, k_{3}$ and $k_{4}$ are the second-order rate constants for the hydronium ion, cleaving agent and hydroxide ion catalyzed cleavage of UpU, respectively. Assuming identical binding of $\mathbf{m U p U}$ and $\mathrm{UpU}$ to the dizinc complex of $\mathbf{2 n}$, the equilibrium data obtained at $90{ }^{\circ} \mathrm{C}$ by spectrophotometric titrations allows 40 one to calculate the concentration of the reactive ternary species at any $\mathrm{pH}^{*}$, providing a more accurate treatment of the kinetic data in the case of this ligand. Thus eqn. (2) is simplified to eqn. (3).

45

$$
k_{o b s}^{c l}=k_{1}\left[\mathrm{H}^{+}\right]+k_{2}+k_{3}\left[\mathrm{Zn}_{2}: \mathbf{2 n}: \mathrm{UpU}\right]+\frac{k_{4} K_{W}}{\left[\mathrm{H}^{+}\right]}
$$

The rate and equilibrium constants obtained by nonlinear leastsquares fitting of the experimental data to eqns. (2) and (3) are presented in Table 2 . With $\mathbf{2 n}$, the rate constants obtained by 50 using eqns. (2) and (3) are in good agreement, supporting the validity of our description of kinetic data. The deprotonation of the two N3 nitrogens is strongly cooperative, and the respective dissociation constants cannot be separated based on the kinetic data (or even by the potentiomeric measurements at $25{ }^{\circ} \mathrm{C}$ ), 55 except in the case of $\mathbf{2 i}$. Therefore, for the other cleaving agents, only the sum $\mathrm{p} K_{\mathrm{a} 1}+\mathrm{p} K_{\mathrm{a} 2}$ has been tabulated.

\section{Hydronium ion catalyzed hydrolysis of UpU}

At $\mathrm{pH}<4$, cleavage of $\mathrm{UpU}$ is first-order in $\left[\mathrm{H}_{3} \mathrm{O}^{+}\right]$both in the presence and in the absence of the cleaving agents $2 \mathbf{h}, \mathbf{2} \mathbf{i}, \mathbf{2 n}$ and ${ }_{60}$ 2o. Under these conditions, the uracil bases remain protonated and uncomplexed with the $\mathrm{Zn}^{\mathrm{II}}$ :cyclen moieties and, hence, no rate acceleration by the cleaving agents is expected. In fact, between $\mathrm{pH} 3.5$ and 4 a modest acceleration is observed but it seems that on going to more acidic solutions this difference in the 65 rates of catalyzed and spontaneous reactions disappears. In other words, under acidic conditions there is no contribution to the cleavage of UpU by $\mathbf{2 h}, \mathbf{2 i}, \mathbf{2 n}$ or $\mathbf{2 o}$ but the reaction proceeds as previously described ${ }^{17}$ even when the cleaving agents are present in a considerable excess.

\section{${ }_{70}$ Cleaving agent catalyzed hydrolysis of $\mathbf{U p U}$}

Between pH 5 and 6, the cleavage of UpU is second-order in $\left[\mathrm{OH}^{-}\right]$in the presence of the cleaving agents $\mathbf{2 h}, \mathbf{2 n}, \mathbf{2 o}$, and $\mathbf{2 i}$ and nearly $\mathrm{pH}$-independent in the absence thereof. Over this relatively narrow $\mathrm{pH}$ range, two $\mathrm{pH}$-dependent equilibria prevail, 75 viz. coordination of the $\mathrm{N} 3$ atoms of the uracil bases to the $\mathrm{Zn}^{\text {II }}$ ions of the binuclear $\mathrm{Zn}^{\mathrm{II}}$ complexes of $\mathbf{2 h}, \mathbf{2 i}, \mathbf{2 n}$ and $\mathbf{2 0}$ with concomitant deprotonation. For the coordination equilibria of $\mathbf{2 h}$, 2n and 2o, the average $\mathrm{p} K_{\mathrm{a}}$ value obtained from eqn. (2) is ( $K_{\mathrm{a} 1}$ $\left.+\mathrm{p} K_{\mathrm{a} 2}\right) / 2=6.1$, in excellent agreement with the 80 spectrophotometric titration curve obtained at $90{ }^{\circ} \mathrm{C}$ for the complex of $2^{\prime}$-O-methyluridylyl-3',5'-uridine (8) and $2 \mathbf{n}: 2 \mathrm{Zn}^{\mathrm{II}}$ $(\mathrm{p} K=6.2)$. With the histamine derivative $2 \mathbf{i}$, eqn. (2) gives $\mathrm{p} K_{\mathrm{a} 1}=$ 6.5 and $\mathrm{p} K_{\mathrm{a} 2}=4.9$. The considerable difference between the two equilibrium constants in the case of $\mathbf{2 i}$ is in all likelihood 85 attributable to the coordination ability of the imidazole ring. In other words, in the dinuclear complex $2 \mathbf{i}: 2 \mathrm{Zn}^{\mathrm{II}}$ the imidazole ring is probably coordinated to one of the $\mathrm{Zn}^{\mathrm{II}}$ ion and this $5 \mathrm{~N}$ coordinated zinc has reduced binding ability to the N3 nitrogens 
of $\mathrm{UpU}$ as compared to the other, $4 \mathrm{~N}$-coordinated one. Therefore the $\mathrm{Zn}^{\mathrm{II}}$ promoted deprotonation of $\mathrm{UpU}$ takes place in two separate steps.

Under conditions where the cleaving agent promoted 5 hydrolysis of UpU prevails, the triazine core of the cleaving agents is in the deprotonated neutral ionic form, ${ }^{18}$ suggesting that the cleaving agents function as general base catalysts. The possibility of general acid catalysis cannot be ruled out, however, due to the instability of the $\mathrm{UpU}: 2 \mathrm{Zn}^{\mathrm{II}}: \mathbf{2}$ ternary complexes under 10 conditions where the triazine core of the cleaving agents would be protonated. Mutual isomerization of $2^{\prime}, 5^{\prime}-$ and $3^{\prime}, 5^{\prime}-\mathrm{UpU}$ is

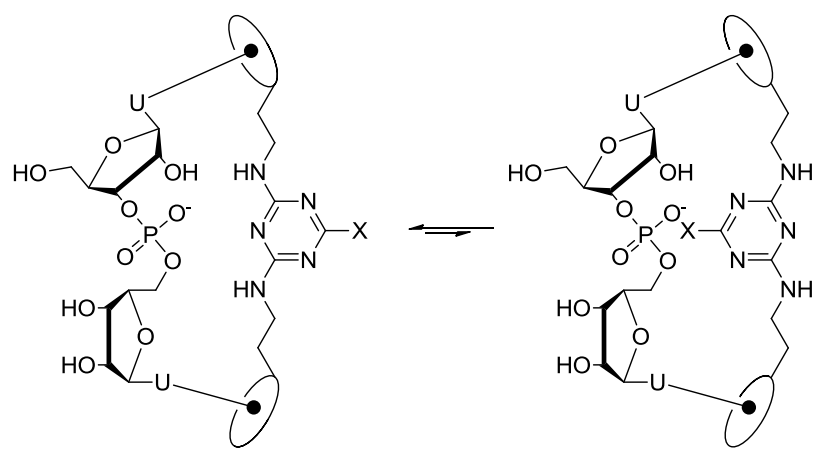

Fig. 8 Two possible conformations of the UpU:cleaving agent complex, with the substituent $\mathrm{X}$ oriented away from (left) or towards (right) the

15 phosphodiester bond.

neither facilitated nor retarded by any of the cleaving agents.

The second-order rate constants for the cleaving agent catalyzed hydrolysis of UpU, $k_{3}$, are nearly identical for $\mathbf{2 h}, \mathbf{2 i}$,

2n and 2o. In other words, the catalytic activity of the cleaving 20 agents is largely independent on the substitution at the 6-position of the triazine ring, even when a potential general acid/base catalyst is attached (the histamine function of $\mathbf{2 i}$ ). In all likelihood, the substituent at the 6-position is oriented away from the scissile phosphodiester bond in the reactive complex which, 25 in turn, suggests that the N3 atom is oriented towards it (Figure 8).

Based on data reported for 2-substituted 4,6-diaminotriazines, the $\mathrm{p} K_{\mathrm{a}}$ value of the triazine ring at $25^{\circ} \mathrm{C}$ can be estimated as $3.96,5.28$ and 3.54 for $\mathbf{2 h}, \mathbf{2 n}$ and $\mathbf{2 0}$, respectively. ${ }^{18}$ In other 30 words, the difference in basicity of nearly 2 logarithmic units is not reflected in the catalytic activity of the cleaving agents. The observed general base catalysis is, hence, probably attributable to sequential specific base and general acid catalysis, with the attacking 2 '-OH being deprotonated in a rapid pre-equilibrium 35 step and proton transfer from the general acid (the protonated triazine) taking place concerted with rate-limiting $\mathrm{P}-\mathrm{O}$ bond fission. ${ }^{19}$ In this kind of mechanism, the effects of the basicity of the general acid/base catalyst are opposite in the two steps: higher basicity shifts the pre-equilibrium to favor the reactive 40 deprotonated species but at the same time retards proton transfer at the rate-limiting step. Apparently, in the present case these two effects completely cancel each other out, indicating that proton transfer from the general acid to the leaving group must be nearly complete at the rate-limiting step. Finally, it should be pointed 45 out that direct general base catalysis, i.e. abstraction of the proton from the $2^{\prime}-\mathrm{OH}$ by the cleaving agent at the rate-limiting step, should result in strong dependence of the reaction rate on the $\mathrm{p} K$

\section{of the triazine ring.}

Together with the exocyclic amino functions at $\mathrm{C} 2$ and $\mathrm{C} 4, \mathrm{~N} 3$ 50 of the triazine ring forms a conjugated network of hydrogen bond donors and acceptors that, upon tautomerization, may abstract and release a proton at any of the three nitrogen atoms. More specifically, this network could mediate proton transfer from the attacking $2{ }^{\prime}-\mathrm{OH}$ to the phosphorane intermediate and, ultimately, 55 to the departing $5^{\prime}$-oxygen, closely mimicking the proposed action of the catalytic guanine moiety in hammerhead and hairpin ribozymes (Scheme 5A). One of the amino groups of the 2,6diaminotriazine core could deprotonate the attacking $2^{\prime}-\mathrm{OH}$ in a pre-equilibrium step and the other one protonate the departing $5^{\prime}$ -
(A)

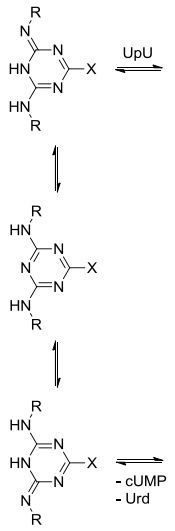

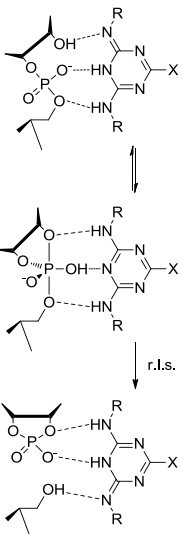

(B)

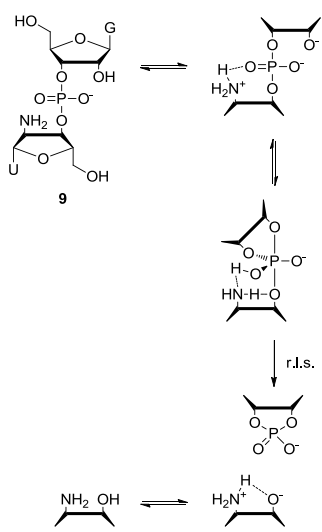

Scheme 5 Proposed mechanisms for (A) cleavage of UpU by $2 \mathbf{h}, \mathbf{2 i}, \mathbf{2 n}$ and 20 and (B) spontaneous cleavage of guanylyl- $\left(3^{\prime}, 3^{\prime}\right)-\left(2^{\prime}\right.$-amino- $2^{\prime}-$ deoxyuridine) (9).

oxyanion in the rate-limiting step. In addition, the protonated N3 65 of the triazine ring may interact with the nonbridging oxygen atoms by hydrogen bonding. In the initial state, the proposed hydrogen bond between the protonated triazine $\mathrm{N} 3$ and the nonbridging oxygen atoms of the phosphodiester linkage is probably a weak one because the monoanionic phosphodiester is 70 only weakly basic. Upon the attack of the 2 -oxyanion on the phosphorus, however, the basicity of the nonbridging oxygen atoms increases, strengthening the hydrogen bond. In the phosphorane intermediate, the proton actually resides on one of the nonbridging oxygen atoms. Upon breakdown of this 75 intermediate, basicity of the nonbridging oxygen atoms decreases again and negative charge builds up on the departing 5 '-oxygen. The 2,6-diaminotriazine core of the cleaving agents may respond to these changes by accepting a proton from a nonbridging oxygen at $\mathrm{N} 3$ and donating another from an exocyclic amino 80 function to the developing $5^{\prime}$-oxyanion.

Although in the present case the catalytic effect of a cleaving agent having the triazine ring protonated could not be studied, previously obtained similar results with simpler model systems tend to support the idea of the deprotonated triazine as a general

85 base catalyst. For example, the cleavage of guanylyl- $\left(3^{\prime}, 3^{\prime}\right)-\left(2^{\prime}-\right.$ amino-2'-deoxyuridine) (9) exhibits a highly similar $\mathrm{pH}$-rate profile but in that case the reaction is first-order in [ $\left.\mathrm{HO}^{-}\right]$between $\mathrm{pH} 4$ and $6 .^{20}$ Because the system is not complicated by coordination equilibria between the nucleobases and cleaving 90 agents this first-order dependence in $\left[\mathrm{HO}^{-}\right]$could be directly attributed to deprotonation of the $2^{\prime}$-amino group. In other words, the $2^{\prime}$-amino function in its deprotonated form is a general base 
catalyst, promoting the cleavage of $\mathbf{9}$. Also in this case, the observed general base catalysis was interpreted in terms of sequential specific base and general acid catalysis, as discussed above (Scheme 5B). ${ }^{19}$

\section{${ }_{5}$ Hydroxide ion catalyzed hydrolysis of UpU}

At $\mathrm{pH}$ 8, hydrolysis of UpU in the presence of the cleaving agents $\mathbf{2 h}, \mathbf{2 i}, \mathbf{2 n}$ and $\mathbf{2 o}$ becomes first-order in $\left[\mathrm{OH}^{-}\right]$. The observed base catalysis in all likelihood refers to rate-limiting departure of the uridine 5'-oxyanion from the marginally stable dianionic 10 phosphorane intermediate formed by attack of the 2 -oxyanion on the phosphorus atom. ${ }^{21}$ The second-order rate constant of the reaction is essentially independent on the presence of the cleaving agents, suggesting that complex formation between UpU and the cleaving agent as such has only a minor impact on the hydrolysis 15 of UpU and the rate acceleration observed at lower $\mathrm{pH}$ is due to the ability of the 2,6-diaminotriazine moiety to facilitate proton transfer from the attacking nucleophile to the phosphorane intermediate and eventually to the departing oxyanion.

\section{Conclusions}

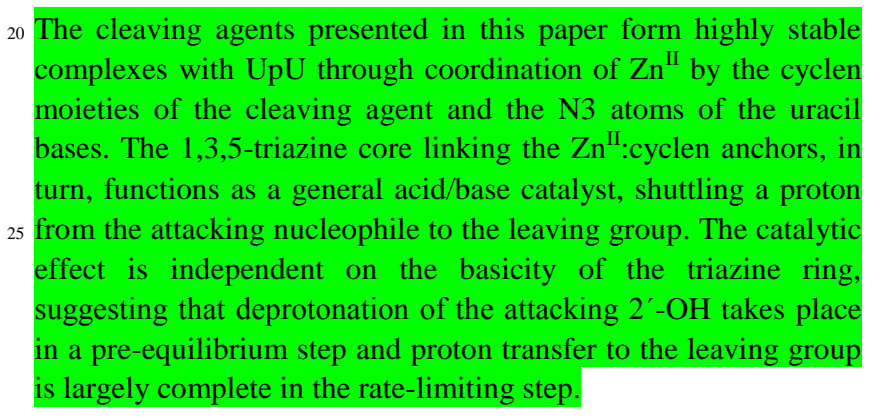

\section{${ }_{30}$ Experimental section}

\section{UV spectrophotometric titrations}

The $\mathrm{pH}$ of $55 \mu \mathrm{mol} \mathrm{L}{ }^{-1}$ solutions of $\mathrm{mUpU}(\mathbf{8})$ in $50 \mathrm{mmol} \mathrm{L}{ }^{-1}$ buffers (MES, HEPES or CHES) were adjusted to the desired value $\left(\mathrm{pH}=8.9\right.$ at $25{ }^{\circ} \mathrm{C}, \mathrm{pH}^{*}=5-7$ at $90^{\circ} \mathrm{C}$. In the latter case 35 the $\mathrm{pH}$ of the solutions was measured at $298 \mathrm{~K}$, and extrapolated to $363 \mathrm{~K}$ using the known $\mathrm{p} K_{\mathrm{a}}$ values of the buffer acids at $363 \mathrm{~K}$ (throughout the paper the extrapolated $\mathrm{pH}$ is designated as $\left.\mathrm{pH}^{*}\right) .^{22} 2.5 \mathrm{~mL}$ of these solutions were placed in a quartz cell having an optical path of $1.0 \mathrm{~cm}$. The temperature of the cell 40 housing block was adjusted to $25.0 \pm 0.1{ }^{\circ} \mathrm{C}$ (or $90 \pm 1{ }^{\circ} \mathrm{C}$ ) and the UV spectra were measured in the wavelength range $200-300$ $\mathrm{nm}$ by a Unicam Helios $\alpha$ spectrophotometer. A more concentrated solution of the ligand $2 \mathrm{n}\left(1.55 \mathrm{mmol} \mathrm{L}^{-1}\right)$ and $\mathrm{Zn}^{\mathrm{II}}$ (3.1 $\mathrm{mmol} \mathrm{L}^{-1}$ ) was added portionwise and the UV-spectrum was 45 measured after each addition. The spectrum of the buffer was subtracted and the dilution of the solution was taken into account before treatment of the data. Equilubrium data from the spectrophotometric titrations were calculated using the PSEQUAD computer program. ${ }^{23}$

\section{${ }_{50}$ pH-Metric measurements}

The protonation and coordination equilibria were investigated by potentiometric titrations in aqueous solution $(I=0.1 \mathrm{M} \mathrm{NaCl}$ and $T=298.0 \pm 0.1 \mathrm{~K}$ ) under argon atmosphere using an automatic titration set including a PC controlled Dosimat 665 (Metrohm) 55 autoburette and an Orion 710A precision digital $\mathrm{pH}$-meter. The Metrohm Micro $\mathrm{pH}$ glass electrode $(125 \mathrm{~mm})$ was calibrated ${ }^{24}$ via the modified Nernst equation (eqn. 4).

$$
E=E_{0}+K \log \left[\mathrm{H}^{+}\right]+J_{\mathrm{H}}\left[\mathrm{H}^{+}\right]+\frac{J_{\mathrm{OH}} K_{\mathrm{w}}}{\left[\mathrm{H}^{+}\right]}
$$

$J_{\mathrm{H}}$ and $J_{\mathrm{OH}}$ are fitting parameters in acidic and alkaline media for the correction of experimental errors, mainly due to the liquid junction and to the alkaline and acidic errors of the glass electrode; $K_{\mathrm{w}}=10^{-13.75} \mathrm{M}^{2}\left(10^{-12.4} \mathrm{M}^{2}\right.$ at $\left.90{ }^{\circ} \mathrm{C}\right)$ is the 65 autoprotolysis constant of water. ${ }^{25}$ The parameters were calculated by the non-linear least squares method. The complex formation was characterized by the following general equilibrium process (eqns. 5 and 6).

70

$$
\begin{gathered}
\mathrm{pM}+\mathrm{qH}+\mathrm{rL}+\mathrm{sA} \stackrel{\beta_{\mathrm{M}_{\mathrm{p}} \mathrm{H}_{\mathrm{r}} \mathrm{L}_{\mathrm{s}} \mathrm{A}_{\mathrm{s}}}^{\longrightarrow}}{\longrightarrow} \mathrm{M}_{\mathrm{p}} \mathrm{H}_{\mathrm{q}} \mathrm{L}_{\mathrm{r}} \mathrm{A}_{\mathrm{s}} \\
\beta_{\mathrm{M}_{\mathrm{p}} \mathrm{H}_{\mathrm{q}} \mathrm{L}_{\mathrm{r}} \mathrm{A}_{\mathrm{s}}}=\frac{\left[\mathrm{M}_{\mathrm{p}} \mathrm{H}_{\mathrm{q}} \mathrm{L}_{\mathrm{r}} \mathrm{A}_{\mathrm{s}}\right]}{[\mathrm{M}]^{\mathrm{p}}[\mathrm{H}]^{\mathrm{q}}[\mathrm{L}]^{\mathrm{r}}[\mathrm{A}]^{\mathrm{s}}}
\end{gathered}
$$

${ }_{75} \mathrm{M}$ denotes the metal ion, $\mathrm{H}$ the hydrogen ions, $\mathrm{L}$ the nonprotonated ligand 2n, while A stands for mUpU (8). Charges are omitted for simplicity, but can be easily calculated taking into account the composition of the fully protonated ligands $\left(\mathrm{H}_{5} \mathrm{~L}^{5+}\right.$

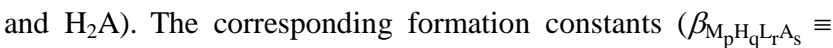
$\left.{ }_{80} \beta_{\mathrm{pqrs}}\right)$ were calculated using the PSEQUAD computer program.

The protonation constants were determined from 3 independent titrations $(60-80$ data points per titration). The complex formation constants were evaluated from $5-10$ independent titrations $(60-100$ data points per titration), 85 depending on the complexity of the system. The metal-to-ligand ratios varied between $1: 4-1: 1$ and $2: 1-1: 2$ in the binary $\mathrm{Zn}^{\mathrm{II}}-$ $\mathrm{mUpU}$ and $\mathrm{Zn}^{\mathrm{II}}$ - 2n systems, respectively, with the $\mathrm{Zn}^{\mathrm{II}}$ concentration in the range of $0.7-1.6 \mathrm{mmol} \mathrm{L}^{-1}$. In the $\mathrm{Zn}^{\mathrm{II}}-\mathbf{2 n}$ - mUpU ternary system the concentration ratios were $2: 1: 1$, 90 $1.5: 2: 1$ and $1: 1: 1$, with the $\mathrm{Zn}^{\mathrm{II}}$ concentration in the range of $0.7-$ $1.6 \mathrm{mmol} \mathrm{L}{ }^{-1}$.

The comparison of the forward and backward titration curves revealed slow kinetics of complex formation processes in the $\mathrm{Zn}^{\text {II }}$ - 2n systems between $\mathrm{pH}$ 3.5-5. To minimize the errors due to 95 the slow kinetics, considerably increased equilibration time has been applied between $\mathrm{pH}$ 3.5-5, which resulted 4-8 h titration time, depending on the metal-to-ligand ratio.

\section{Kinetic measurements}

100 Reactions were carried out in sealed tubes immersed in a thermostated water bath, the temperature of which was adjusted to $90{ }^{\circ} \mathrm{C}$ within $\pm 0.1{ }^{\circ} \mathrm{C}$. The hydronium ion concentration of the reaction solutions was adjusted with formate, acetate, MES and HEPES buffers and sodium hydroxide and checked with a $\mathrm{pH}$ 105 meter. The ionic strength of the solutions was adjusted to 0.10 mol L ${ }^{-1}$ with $\mathrm{NaClO}_{4}$. The initial substrate concentration in the

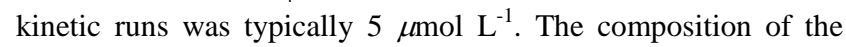
samples withdrawn at appropriate time intervals was analyzed by HPLC on a Hypersil-Keystone Aquasil C18 column $(4 \times 150$ $110 \mathrm{~mm}, 5 \mu \mathrm{m})$ using $0.06 \mathrm{~mol} \mathrm{~L}^{-1}$ acetate buffer and $\mathrm{MeOH}$ as an eluent. For the first 10 min, only buffer was used, after which the 
amount of $\mathrm{MeOH}$ was increased linearly from to $30 \%$ during 5 min and kept there for another $5 \mathrm{~min}$. The observed retention times $\left(t_{\mathrm{R}}, \mathrm{min}\right)$ for the hydrolytic products of UpU were as follows: $16.0\left(3^{\prime}, 5^{\prime}-\mathrm{UpU}\right), 15.3\left(2^{\prime}, 5^{\prime}\right.$-UpU), 6.5 (Urd), $5.2\left(2^{\prime}\right.$ 5 UMP), 4.6 ( $3^{\prime}$-UMP), 3.8 ( $2^{\prime}, 3^{\prime}$-cUMP). The products were characterized by spiking with authentic samples. For the experiments carried out in the presence of an excess of the cleaving agent, pseudo first-order rate constants for the disappearance of UpU were obtained by applying the integrated

10 first-order rate law to the time-dependent diminution of the relative peak area of UpU. When the reaction rate was studied as a function of $\mathrm{UpU}$ concentration at a constant limiting concentration of the cleaving agent, initial rates were obtained as slopes of the plots of the combined peak area of all the 15 monomeric products $\left(2^{\prime}, 3^{\prime}\right.$-cUMP, 3'-UMP, 2'-UMP and uridine) as a function of reaction time.

\section{Acknowledgements}

Financial support from the Academy of Finland and from the Hungarian Scientific Research Found (OTKA K63606) is 20 greatfully acknowledged.

\section{Notes and references}

${ }^{a}$ Department of Chemistry, University of Turku, FIN-20014, Turku, Finland. Fax: +3582333 6700; Tel: +358 2333 6777; E-mail: tuanlo@utu.fi

$25{ }^{b}$ Department of Inorganic and Analytical Chemistry, University of Szeged, Address, H-6701, P.O. Box 440, Szeged, Hungary. Fax: +3662 544 054; Tel: +36 62420 505; E-mail: tamas.gajda@chem.u-szeged.hu $\dagger$ Electronic Supplementary Information (ESI) available: Synthetic details and ${ }^{1} \mathrm{H}$ and ${ }^{13} \mathrm{C}$ NMR spectra for compounds $5,6,7,2 \mathbf{h}, 2 \mathbf{i}, 2 \mathbf{n}, 2 \mathrm{o}$ and 8 ,

${ }^{30}{ }^{31} \mathrm{P}$ NMR spectrum for compound $\mathbf{8}$ and an example illustrating the fitting of the potentiometric data. See DOI: 10.1039/b000000x/

1 S. A. Strobel, Nat. Chem. Biol., 2005, 1, 5; P. C. Bevilacqua and R. Yajima, Curr. Opin. Chem. Biol., 2006, 10, 455.

2 D. M. Perrault and E. V. Anslyn, Angew. Chem. Int. Ed. Engl., 1997,

35 36, 432; M. Oivanen, S. Kuusela and H. Lönnberg, Chem. Rev., 1998, 961; R. Breslow, S. D. Dong, Y. Webb and R. Xu, J. Am. Chem. Soc., 1996, 118, 6588; A. J. Kirby and R. E. Marriott, J. Chem. Soc., Perkin Trans. 2, 2002, 422.

3 D. A. Usher and A. H. McHale, Proc. Natl. Acad. Sci. USA, 1976, 73, 1149 .

4 S. Aoki and E. Kimura, Chem. Rev., 2004, 104, 769; E. Kimura, T. Shiota, M. Koike, M. Shiro and M. Kodama, J. Am. Chem. Soc., 1990, 112, 5805.

5 Q. Wang and H. Lönnberg, J. Am. Chem. Soc., 2006, 128, 10716.

456 P. B. Rupert and A. R. Ferré-D'Amaré, Nature, 2001, 410, 780; M. Martick and W. G. Scott, Cell, 2006, 126, 309; J. Han and J. M. Burke, Biochemistry, 2005, 44, 7864.

7 S. Kuusela and H. Lönnberg, J. Phys. Org. Chem., 1993, 6, 347; S. Kuusela and H. Lönnberg, J. Phys. Org. Chem., 1992, 5, 803.

508 E. Kimura, S. Aoki, T. Koike and M. Shiro, J. Am. Chem. Soc., 1997, 119, 3068.

9 J. Farràs, X. Ginesta, P. W. Sutton, J. Taltavull, F. Egeler, P. Romea, F. Urpí and J. Villarasa, Tetrahedron, 2001, 57, 7665.

10 N. Ogasawara and Y. Inoue, J. Am. Chem. Soc., 1976, 98, 7048.

5511 C. F. Baes and R. E. Mesmer, The hydrolysis of Cations, John Wiley \& Sons, New York, 1976.

12 P. Davies and K. Wainwright, Inorg. Chim. Acta, 1999, 294, 103.

13 M. Shionoya, E. Kimura and M. Shiro, J. Am. Chem. Soc., 1993, 115, 6730.

6014 E. Kimura, M. Kikuchi, H. Kitamura and T. Koike, Chem. Eur. J., 1999, 5, 3113.
15 C. Anda, A. Bencini, E. Berni, S. Ciattina, F. Chuburu, A. Danesi, C. Giorgi, H. Handel, M. Le Baccon, P. Paoletti, R. Tripier, V. Turcy and B. Valtancoli, Eur. J. Inorg. Chem., 2005, 2044.

6516 R. Haidar, M. Ipek, B. DasGupta, M. Yousaf, and L.J. Zompa, Inorg. Chem. 1997, 36, 3125.

17 P. Järvinen, M. Oivanen and H. Lönnberg, J. Org. Chem., 1991, 56, 5396.

18 T. Tashiro, J. Heterocyclic. Chem., 2002, 39, 615.

7019 M. Kosonen and H. Lönnberg, J. Chem. Soc., Perkin Trans 2, 1995, 1203.

20 M. Ora, H. Linjalahti and H. Lönnberg, J. Am. Chem. Soc., 2005, 127, 1826.

21 H. Lönnberg, R. Strömberg and A. Williams, Org. Biomol. Chem., 2004, 2, 2165

22 H. S. Harned, B. B. Owen, The Physical Chemistry of Electrolytic Solutions, Reinhold Pub., New York, 1958.

23 L. Zékány, I. Nagypál, G. Peintler, PSEQUAD for chemical equilibria, Technical Software Distributors, Baltimore, 1991.

8024 F. J. C. Rosotti, H. Rosotti, in The determination of stability constants, McGraw-Hill Book Co., New York, 1962, pp. 149.

25 E. Högfeldt, in Stability Constants of Metal-Ion Complexes, Part A. Inorganic Ligands, Pergamon, New York, 1982, pp. 32. 